\title{
Hydrological Processes and Climate Change in Hydrographic Regions of Brazil
}

\author{
Alfredo Ribeiro Neto', Adriano Rolim da Paz², José Antonio Marengo ${ }^{3}$, Sin Chan Chou ${ }^{4}$ \\ ${ }^{1}$ Civil and Environmental Engineering Department, Federal University of Pernambuco, Recife, Brazil \\ ${ }^{2}$ Civil and Environmental Engineering Department, Federal University of Paraíba, Joao Pessoa, Brazil \\ ${ }^{3}$ National Center for Monitoring and Early Warning of Natural Disasters, São José dos Campos, Brazil \\ ${ }^{4}$ Center for Weather Forecasts and Climate Studies, National Institute for Space Research, Cachoeira Paulista, Brazil \\ Email:alfredoribeiro@ufpe.br, adrianorpaz@yahoo.com.br, jose.marengo@cemaden.gov.br,chou@cptec.inpe.br
}

How to cite this paper: Neto, A.R., da Paz, A.R., Marengo, J.A. and Chou, S.C. (2016) Hydrological Processes and Climate Change in Hydrographic Regions of Brazil. Journa of Water Resource and Protection, 8, 1103 1127.

http://dx.doi.org/10.4236/jwarp.2016.812087

Received: October 4, 2016

Accepted: November 4, 2016

Published: November 7, 2016

Copyright $\odot 2016$ by authors and Scientific Research Publishing Inc. This work is licensed under the Creative Commons Attribution International License (CC BY 4.0).

http://creativecommons.org/licenses/by/4.0/

\section{Abstract}

The objective of this work is to assess the impacts of IPCC AR5 climate change scenarios on water resources and hydrological processes across the entire Brazilian territory. Hydrological simulations are carried out in total drainage area of about $11,535,645 \mathrm{~km}^{2}$ and average stream flow of about $272,460 \mathrm{~m}^{3} / \mathrm{s}$. The study area consists of different climates and land covers such as the Amazon Forest, Northeast Semiarid, Brazilian Savannah, Pantanal wetlands and temperate climate in the South. The atmospheric forcing to drive the large-scale hydrological model MGB-IPH is derived from the downscaling of two global climate models, HadGEM2-ES and MIROC5, by the Eta Regional Climate Model, at $20 \mathrm{~km}$ resolution. The Eta model provided the downscaling of the baseline (1961-1990) and three time-slices (20112040, 2041-2070 and 2071-2099). These projections adopted two emission scenarios, the RCP 4.5 and RCP 8.5. The change in the average and extremes of precipitation, evapotranspiration, rates of river discharge and soil moisture were assessed. The simulations showed the response of the hydrographic regions due to change of precipitation and potential evapotranspiration in the scenarios. Water availability decreases in almost the entire study area (exception for the South) and the major basins for hydroelectric power generation are affected. The Northwest, Amazon and a small area along the Northeast Atlantic coast exhibited intensification of the extremes discharges, where the anomaly is positive for high-flow $\left(Q_{10}\right)$ and negative for low-flow $\left(Q_{95}\right)$. The results highlight the most climatic sensitive regions in Brazil in terms of hydrological variables and water resources.

\section{Keywords}

Hydrological Modelling, IPCC Scenarios, Climate Change, Impacts 


\section{Introduction}

In the natural system of a watershed, a number of hydrological processes take place in different space-time frequencies and scales, influenced by physical characteristics related to soil, vegetation, geology, relief, and the drainage network, as well as by prevailing meteorological conditions and mostly the characteristics of the rainfall event. The spatio-temporal patterns that characterize the hydrological response of a watershed may be altered due to changes in climate. These alterations may vary in intensity according to climate characteristics, dry or wet lands, and the magnitude of the change. Global climate changes are expected to take place in the next decades as a result of population growth, land use change and climate change. The Intergovernmental Panel on Climate Change-IPCC Fourth (AR4) and Fifth (AR5) Assessment Reports (available from: www.ipcc.ch) highlight the regions on earth that are more vulnerable to climate change, changes such as the increase or decrease of the total annual precipitation and by dryness or wetness that on the long-term affect the basin-scale water budget. Magrin et al. (2014) [1] identified changes in stream flow and water availability that are projected to continue into the future in South America, affecting already vulnerable regions. Increasing runoffs in the La Plata River basin and decreasing ones in the Central Andes (Chile, Argentina) in the second half of the 20th century have been associated with changes in precipitation. The current strategy for estimating impacts of climate scenarios on river flow regimes is to use the Global Circulation Models (GCM) outputs as input for hydrological models. These studies may focus on hydrographic basin scale [2] [3] [4] or global scales [5] [6] [7] [8]. Arnell and Gosling (2013) [6] have used 21 GCMs and the global hydrological model Mac-PDM0.09 at a spatial resolution of $0.5^{\circ} \times$ $0.5^{\circ}$. A quarter of the globe had an increase in runoff in more than two-thirds of GCMs. Nakaegawa et al. (2013) [7] simulated 24 large river basins around the globe using the MRI-AGCM3.1 GCM (20 km spatial resolution) and TRIP river flow model ( $0.5^{\circ}$ spatial resolution). The simulations projected annual runoff reduction in seven river basins and an increase in runoff in seventeen river basins.

In addition to runoff, other hydrological processes are influenced by climate change and the impacts have been studied under the various IPCC scenarios. For example, a seasonal impact resulted from IPCC scenarios was reported by [9] in South Korea, [10] in China and [11] in the River Rhine basin. Arnell and Gosling (2013) [6] have evaluated the changes in December, January, February (DJF) and June, July, August (JJA) runoff across the global domain. The results showed similar changes in the summer and winter seasons across Brazil. In the other parts of South America, the increase in runoff occurs in JJA. Nakaegawa et al. (2013) [7] verified that the Amazon River runoff would increase in the high-water season and decrease in low-water, characterizing an amplitude of the seasonal cycle. In the same study, the Parana River had different changes along the basin for the same season (upstream increases less than downstream).

Jung et al. (2013) [9] evaluated seasonal runoff impacts in South Korea using 13 GCMs with three emission scenarios and three hydrological models. The simulations 
showed the territory has different responses to scenarios, during the dry season, North is wetter and South is drier, whilst during the wet season, there is flow increase throughout the country. Similar results were obtained by [10] in the Wei River Basin, China. The hydrological model SWAT simulated scenarios A2 and B1 using precipitation from three GCMs and found a decrease in the low-flow ( $Q_{90}$ in the flow duration curve) and an increase in the high-flow ( $Q_{10}$ in the flow duration curve), suggesting more extreme events of droughts and floods. Demirel et al. (2013) [11] used three GCMs and three IPCC scenarios in the River Rhine basin upstream from the DutchGerman border. The results showed a shift of the low flows from winter to summer.

In Brazil, studies have identified discharge reduction for semiarid land in Northeast Brazil [12] [13] [14] [15] [16]. Northeast Brazil is included in those arid or semiarid lands particularly exposed to the impacts of climate change on freshwater [17]. In other regions of Brazil, other authors have found projected runoff decreasing in the Amazon region [3] [14], increasing and decreasing runoff (the signal depends on the GCM used) in the Southeast (Grande River) [4] [18], and increasing in hydrographic regions in the Southern Brazil region [1] [14]. Risk of water supply shortages will increase owing to precipitation reduction and evapotranspiration increase in semiarid regions, thus affecting water supply for cities, hydropower generation and agriculture. All these works have assessed the impacts under IPCC AR4 scenarios.

An increase in precipitation and a reduction in evapotranspiration from land use changes have been associated with the trend in stream flow of the Parana-Plata river [19] [20], with the former being more important in the southern sub-basins and the latter in the northern ones [20]. There is no clear long-term trend for the Amazon River. Marengo and Espinoza (2015) [21] and references cited by them indicate that in the 1974-2004 period apparent stability in mean discharge at the main stem of the Amazon in Obidos can be explained by opposing regional features of Andean rivers (e.g., increasing trends during the high-water period in the Peruvian and Colombian Amazon regions; and decreasing trends during the low-water period in the Peruvian and Bolivian Amazons [22]). In recent years, extremely low levels were experienced during the droughts of 2005 and 2010, while record high levels were detected during the 2009 and 2012 floods. Major Colombian rivers draining to the Caribbean Sea (Magdalena and Cauca) exhibit decreasing trends along their main channels [23], while significant trends are absent for all other major large rivers in Northeast Brazil and northern South America [24]. The works by [14] and [16] projects large reduction in runoff in the Amazon and São Francisco Basins, while increases are reported at the Parana River in southern Brazil. These rivers fill the reservoirs that furnish and sustain the water and energy resources throughout Brazil.

In view of the observed runoff trends in South America and Brazil, and of the projected trends derived from global and regional models, the objective of this study is to assess the impacts of climate change on the water budget and seasonal stream flow in Brazilian hydrographic regions using the new regional climate change projections from the global HadGEM2-ES (Hadley Global Environment Model 2-Earth System) and 
MIROC5 (Model for Interdisciplinary Research On Climate) IPCC AR5 models simulated by the Eta regional model. The study is based on the downscaling of the climate simulations from two GCMs and two AR5 emission scenarios, RCP 4.5 and 8.5. The projections are assessed in three time slices: 2011-2040, 2041-2070 and 2071-2099. The study area comprises the entire Brazilian territory and parts of neighboring South American countries included in the delimitation of the Brazilian hydrographic regions. The impacts of the projected hydrological scenarios are assessed in terms of precipitation, soil moisture, evapotranspiration and runoff. Comparison of changes among the different basins may help to identify the most vulnerable river basins as well as the most resilient ones. The novelties of this work are the use of higher resolution downscaling simulations, at $20-\mathrm{km}$ resolution, in the assessment of all major Brazilian river basins, and the use of AR5 IPCC scenarios. The higher spatial resolution improves the descriptions of topography and land cover in a river basin. Previous works have used coarser resolutions for their assessment, studied fewer river basins, and adopted AR4 scenarios.

Section 2 shows the methodology used, describing the study area, the climate and hydrological dataset, the hydrological model and the hydrological indicators selected for the analysis. Section 3 presents the verification of the discharges simulated with the models and the spatial patterns of changes in precipitation, runoff, evapotranspiration, soil moisture, water budget, seasonal runoff and extreme discharges. The last section shows the conclusion of the work taking into account the impacts on the hydrology for establishing adaptation measures.

\section{Methodology}

\subsection{Study Area}

Brazil is the fifth largest country in the world with $8,511,965.0 \mathrm{~km}^{2}$. The Brazilian National Water Agency (ANA) established the National Hydrographic Division comprising 12 regions. The present study bases spatial discretization on the National Hydrographic Division, but with more details and considering the land beyond the Brazilian border, making the area studied a total of $11,535,645.3 \mathrm{~km}^{2}$. Figure 1 shows the seventeen hydrographic regions defined in the study with their respective drainage areas.

The study area has different climate regimes and land covers, such as tropical forests (Amazon), savannas (Cerrado), semi-arid (Northeast region), wetlands (Pantanal) and temperate climate in the South. Therefore, the major Brazilian river basins may present distinct hydrologic responses induced by climate changes. On the average along time, the entire study area has a contribution of $272,460.0 \mathrm{~m}^{3} / \mathrm{s}$.

\subsection{Climate and Hydrological Datasets}

The downscaling of climate simulations and projections was provided by the Eta regional climate model (RCM). The Eta model [25] [26] [27] is an atmospheric regional model used operationally by the Brazilian Center for Weather Forecasts and Climate Studies for weather forecasts since 1996 [28] and for seasonal forecasts since 2002 [29]. The model was modified and validated to be suitable for climate changes studies [14] 


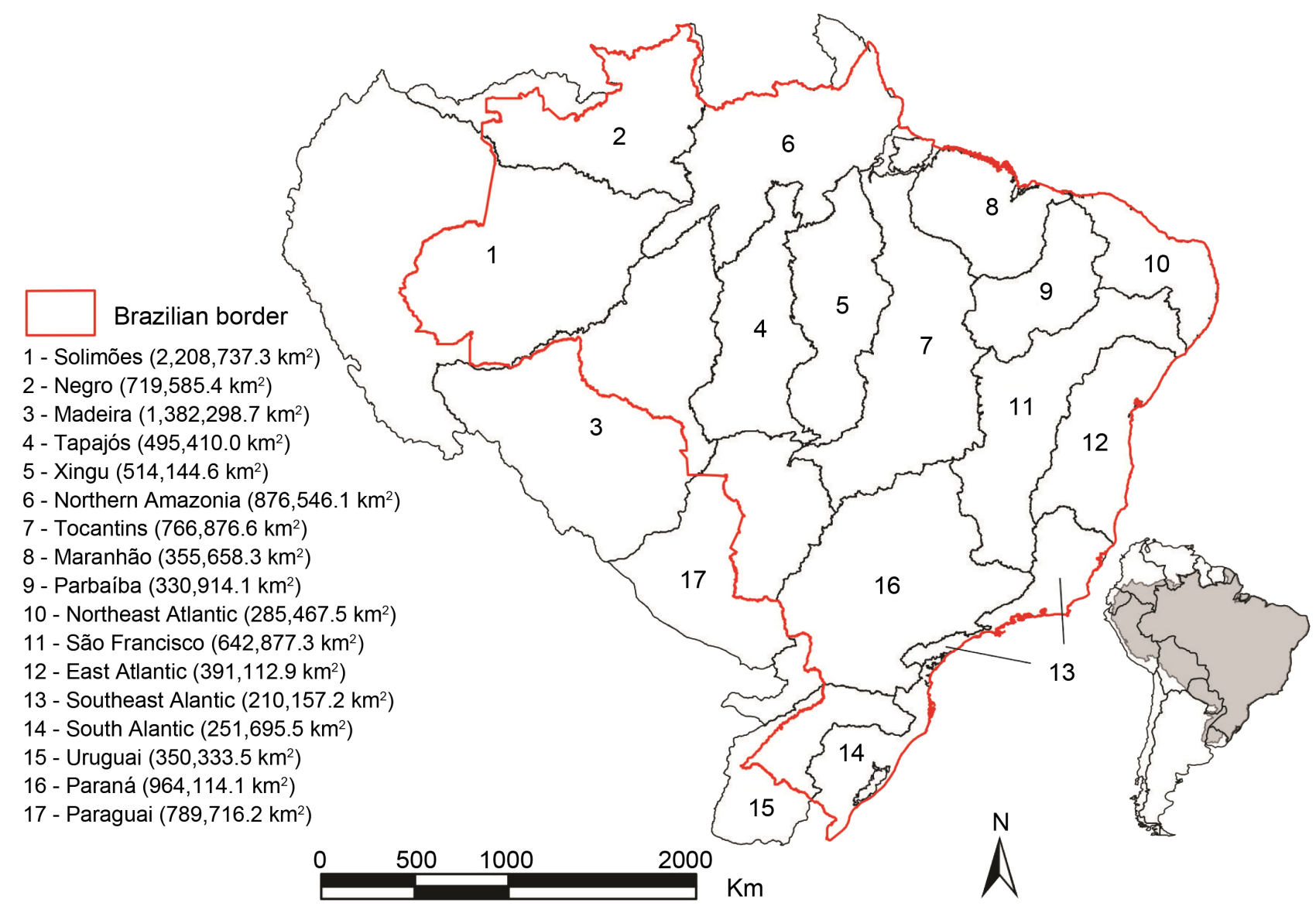

Figure 1. Hydrographic regions in the study area.

[30] [31]. The name of the model stands for the Greek letter $\eta$ that defines the model vertical coordinate. This coordinate was developed by [32] to reduce the errors of the terrain-following coordinate (the $\sigma$ coordinate) in the calculations of pressure gradient near sloping topography. As shown by [33], the $\eta$ coordinate is more suitable to simulate the large-scale circulation over the South America due to the presence of the Andes Cordillera. The current version of the Eta regional climate model has received upgrades in the dynamics and physics components [34].

The downscaling of two global climate model simulations, HadGEM2-ES and MIROC5, by the Eta model has been evaluated [35] and future climate projections were assessed [36]. A 30-year baseline period was taken between 1961 and 1990. The future period was divided into three time-slices of 30 years: 2011-2040, 2041-2070, and 2071-2099, under RCP 4.5 and RCP 8.5 IPCC AR5 scenarios. The spatial resolution of the Eta model was $20 \mathrm{~km}$ in the horizontal with 38 layers in the vertical.

Precipitation, air temperature, net radiation, relative humidity, wind speed, and surface pressure are the atmospheric variables that drive the hydrological model. Precipitation input is on a daily basis, while the other variables are considered as mean monthly values for calculation of the evapotranspiration using the Penman-Monteith method. The mean monthly values are taken from the average of each time-slice of 
thirty years. For more information on the characteristics of the Eta regional model and the HadGEM2-ES and MIROC5 global models, please refer to [35] [36] and references quoted in that paper.

The observed rainfall from the Climatic Research Unit database CRU TS 2.1 [37] was used for comparison between measured and simulated precipitation. The time series used from CRU TS 2.1 has a monthly time step and spatial resolution of 0.5 degrees. The CRU precipitation dataset was used to correct the bias error of RCM precipitation predictions prior to the input to the hydrological model, by using cumulative distribution functions (CDFs) according to [38].

River discharges were used to verify the hydrological model simulation of the present-day climate. The 95 daily discharge time series were taken from stream gauges of the Brazilian National Water Agency's (ANA) hydrometeorological network. Eleven of the 17 hydrographic regions correspond to a specific river basin: Solimões, Negro, Madeira, Tapajós, Xingu, Tocantins, Parnaíba, São Francisco, Uruguay, Paraná and Paraguay. For each of them, the discharges used for comparison in this study were obtained based on the most downstream stream gauge with available observed data, considering the ratio between drainage areas of the hydrographic region and the stream gauge. The other six hydrographic regions (Northern Amazon, Maranhão, Northeast Atlantic, East Atlantic, Southeast Atlantic and South Atlantic) comprise many river basins and observed data from a total of 84 stream gauges was used to obtain the average observed discharges for each of them, again taking into account the drainage area of each stream gauge. The discharge data from the stream gauges was used for obtaining mean annual flows, $Q_{95}, Q_{10}$ and a set of twelve values from January to December corresponding to mean monthly discharges.

\subsection{Hydrological Model}

A large scale distributed hydrological model called MGB-IPH (an acronym from the Portuguese for Large Basins Model and Institute of Hydraulic Research) [39] was used in the simulations. This model has been widely applied in distinct South-American watersheds, for different purposes, such as stream flow forecasting [40], simulation of land-use changes [41], evaluation of climate change impacts [4], assessment of hydrological processes [2]. The MGB-IPH model may be distributed by cells or catchments and runs in daily time steps. The cell version of the model was used in this work, considering a regular square-based grid of $0.2^{\circ} \times 0.2^{\circ}$. In this model, each cell is divided into hydrological response units (HRU), called patches, which are the combination of unique land-use, vegetation, and soil type. Each HRU has a uniform hydrological response to meteorological forcing.

MGB-IPH follows the Xinanjiang model formulation [42] to calculate the soil water budget. Three linear reservoirs are used to represent independent routing of surface, subsurface and groundwater flow through the cell. Potential evapotranspiration is calculated by the Penman-Monteith equation. The original version of the MGB-IPH simulates flow propagation in the rivers using the Muskingum-Cunge method; and further studies have included hydrodynamic modelling [43]. In the present study, however, 
river flow routing was eliminated and the MGB-IPH run as the global hydrological model Mac-PDM0.09, that is, the model does not route water from one cell to other [5].

The hydrological model needs information about soil type and land cover to determine the HRU. The soil type was obtained from the Digital Soil Map of the World created by FAO on a scale of 1:5,000,000 [44] and the land cover map was obtained from the Joint Research Centre [45]. In the present study, seventeen HRUs were considered in the MGB-IPH. The digital terrain model (DTM) was used for calculation of the time of concentration in each cell of the model. The elevation is represented by the SRTM DTM processed by the Hydrosheds [46].

Some of the MGB-IPH model parameters are generally calibrated according to observed and calculated hydrograph comparisons, manually or using an optimization algorithm, as described in [39]. In the present study, the model parameters were not calibrated due to lack of available stream flow data for the entire area. The alternative was to use the values of the parameters obtained from earlier applications of the MGB-IPH in some Brazilian river basins [2] [39] [40]. As described in the prior section, the climate data simulated by Eta model is used as input for the MGB-IPH simulations, which comprise the baseline (1961-1990) and three time-slices (2011-2040, 2041-2070 and 2071-2099) for HadGEM2-ES (RCP 4.5 and 8.5) and MIROC5 (RCP 8.5). The results of the simulation using precipitation from climate models and baseline period were compared with the discharge estimated with time series from stream gauges as mentioned before.

\subsection{Hydrological Indicators}

The processes were analyzed in terms of anomalies of long-term annual average and seasonal average. Precipitation, average river discharge, evapotranspiration and soil moisture were calculated for each hydrographic region.

The seasonality was calculated using river discharges from December, January and February (DJF) for austral summer, and June, July and August (JJA) for austral winter. The goal is to verify if the seasonal changes are equivalent or different to annual average changes under the climate change scenarios. In addition, the seasonal amplitude was calculated using the difference between the maximum and minimum average monthly stream flow according to [6].

The extreme values of river discharge are assessed using a duration curve for each cell model. The high-flow is represented by the $Q_{10}$ (flow exceeded $10 \%$ of the time) and the low-flow is represented by the $Q_{95}$ (flow exceeded $95 \%$ of the time).

\section{Results and Discussion}

Initially, simulations of the river discharge for the baseline period are evaluated. The projections are shown in terms of changes in runoff, water budget, seasonality and extreme discharges.

\subsection{Discharge Verification}

The hydrological model was simulated for the present-day climate (1961-1990) using 
variables calculated by climate models. River discharge ratio (RDR) and correlation coefficient $\left(\mathrm{R}^{2}\right)$ were used to evaluate the hydrological model performance. RDR is the ratio between discharges simulated and observed. The correlation coefficient was determined using the mean monthly discharges observed and simulated by the MGBIPH/Eta models. Table 1 shows the values obtained from the downscaling by the regional Eta model and MGB-IPH. From now on, the downscaling of the Eta model from the HadGEM2-ES will be referred to as Eta-HadGEM2-ES, and the downscaling from the MIROC5 will be referred to as Eta-MIROC5.

Analyzing the simulations of the MGB-IPH driven by Eta-HadGEM2-ES, fourteen of the hydrographic regions presented RDR within $\pm 30 \%$ of ideal value RDR (100\%). For the regions Xingu, Northern Amazon and Paraguay, however, the river discharges were overestimated and the corresponding RDR fell out of the ideal range. Similar performance was simulated by the MGB-IPH/Eta-MIROC5 model. The correlation coefficient calculated between mean monthly observed and simulated discharges roughly indicate the agreement between them in terms of reproducing the overall flow regime and seasonality in each hydrographic region. The results obtained were satisfactory, with 12 of the 17 regions with $\mathrm{R}^{2}$ greater than 0.7 . Four regions presented $\mathrm{R}^{2}$ lower than 0.5 , due to the difficulty in representing the seasonality of the discharge in the basins. The

Table 1. Statistics of observed and calculated river discharges.

\begin{tabular}{|c|c|c|c|c|c|c|c|}
\hline \multirow{2}{*}{ Hydrographic Region } & \multirow{2}{*}{ Observed $\left(\mathrm{m}^{3} / \mathrm{s}\right)^{\mathrm{a}}$} & \multicolumn{3}{|c|}{ MGB-IPH/Eta-HadGEM2-ES } & \multicolumn{3}{|c|}{ MGB-IPH/Eta-MIROC5 } \\
\hline & & Baseline $\left(\mathrm{m}^{3} / \mathrm{s}\right)$ & RDR (\%) & $\mathrm{R}^{2}$ & Baseline $\left(\mathrm{m}^{3} / \mathrm{s}\right)$ & RDR (\%) & $\mathrm{R}^{2}$ \\
\hline Solimões & $101,916.2$ & $83,292.6$ & 81.7 & 0.41 & $78,409.7$ & 76.9 & 0.46 \\
\hline Negro & $43,349.3$ & $31,981.8$ & 73.8 & 0.98 & $31,618.6$ & 72.9 & 0.99 \\
\hline Madeira & $28,452.0$ & $28,368.5$ & 99.7 & 0.78 & $29,589.4$ & 104.0 & 0.80 \\
\hline Xingu & 9130.8 & 15293.7 & 167.5 & 0.98 & $16,346.3$ & 179.0 & 0.98 \\
\hline Tapajós & 13167.4 & $13,246.8$ & 100.6 & 0.96 & $14,708.7$ & 111.7 & 0.96 \\
\hline Northern Amazon & $21,092.6$ & $29,212.0$ & 138.5 & 0.92 & $30,650.5$ & 145.3 & 0.94 \\
\hline Tocantins & $13,040.5$ & $10,471.0$ & 80.3 & 0.97 & $13,636.6$ & 104.6 & 0.96 \\
\hline Maranhão & 3561.5 & 3627.3 & 101.8 & 0.49 & 4400.3 & 123.5 & 0.52 \\
\hline Parnaíba & 894.2 & 707.1 & 79.1 & 0.65 & 848.7 & 94.9 & 0.61 \\
\hline Northeast Atlantic & 671.8 & 826.7 & 123.0 & 0.49 & 842.5 & 125.4 & 0.45 \\
\hline São Francisco & 2892.9 & 2726.1 & 94.2 & 0.99 & 2971.9 & 102.7 & 0.99 \\
\hline East Atlantic & 1343.9 & 1571.1 & 116.9 & 0.84 & 1666.1 & 123.9 & 0.78 \\
\hline Southeast Atlantic & 2747.4 & 2449.1 & 89.1 & 0.99 & 2728.0 & 99.3 & 0.98 \\
\hline South Atlantic & 6194.4 & 4885.4 & 78.9 & 0.91 & 4416.6 & 71.3 & 0.92 \\
\hline Uruguay & 8749.6 & 7790.8 & 89.0 & 0.88 & 7481.2 & 85.5 & 0.76 \\
\hline Parana & $12,013.2$ & $11,913.5$ & 99.2 & 0.92 & $13,442.6$ & 111.9 & 0.96 \\
\hline Paraguay & 3242.3 & 4527.7 & 139.6 & -0.65 & 4614.6 & 142.3 & -0.55 \\
\hline
\end{tabular}

a. annual average for baseline period. 
extreme situation is verified in the Paraguay river basin where the flood and drought flows were completed inverted (negative $\mathrm{R}^{2}$ ) due to the strong water storage effect of the Pantanal wetland [47]. As mentioned before, the version of the MGB-IPH used in the present work does not represent the river flow routing, which prevent the simulation of the storage in the Pantanal.

The verification of the extreme stream flows $Q_{95}$ and $Q_{10}$ exhibited inferior quality in comparison to the verification of the mean annual stream flow. The RDR of the $Q_{95}$ stream flow varied from 21.9\% (Tapajós basin and MGB-IPH/Eta-HadGEM2-ES) to 203.7\% (Northeast Atlantic and MGB-IPH/Eta-MIROC5). The overall result for the entire study area is an underestimate of the $Q_{95}\left(46,350 \mathrm{~m}^{3} / \mathrm{s}\right.$ and $41,870 \mathrm{~m}^{3} / \mathrm{s}$, respectively, from MGB-IPH/Eta-HadGEM2-ES and MGB-IPH/Eta-MIROC5 against the observed value of $107,041 \mathrm{~m}^{3} / \mathrm{s}$ ). The RDR of the $Q_{10}$ stream flow varied from $64.0 \%$ (South Atlantic and MGB-IPH/Eta-MIROC5) to 203.0\% (Paraguay basin and MGB-IPH/EtaMIROC5). The overall result for the entire study area is an overestimate of the $Q_{10}$ (541,091 $\mathrm{m}^{3} / \mathrm{s}$ and 550,439 $\mathrm{m}^{3} / \mathrm{s}$, respectively, from MGB-IPH/Eta-HadGEM2-ES and MGB-IPH/Eta-MIROC5 against the observed value of 474,605 $\mathrm{m}^{3} / \mathrm{s}$ ). The maximum RDR values of $Q_{95}$ and $Q_{10}$ probably are influenced, respectively, by the low observed discharge in Northeast Atlantic $\left(Q_{95}=42.2 \mathrm{~m}^{3} / \mathrm{s}\right)$ and the storage effect in Pantanal wetlands.

\subsection{Changes of Precipitation and Runoff}

The projections were produced after the definition of the hydrological model parameters. The simulations enabled evaluation of the sensitivity of the hydrographic regions in relation to the precipitation changes. The sensitivity of long-term stream flow to changes in long-term rainfall may be evaluated by using the concept of elasticity. The rainfall elasticity of stream flow is defined as the proportional change in mean annual stream flow divided by the proportional change in mean annual rainfall [48].

$$
E l=\frac{Q_{\text {sce }}-Q_{\text {base }}}{P_{\text {sce }}-P_{\text {base }}}
$$

where

$E l$ is the elasticity

$Q_{s c e}$ is the MGB-IPH discharge of the scenario

$Q_{\text {base }}$ is the MGB-IPH discharge of the baseline (1961-1990)

$P_{s c e}$ is the Eta precipitation of the scenario

$P_{\text {base }}$ is the Eta precipitation of the baseline (1961-1990)

Mean values for the entire study area are shown in Table 2 . The elasticity varied from 0.54 to 9.79 , with a global weighted average of 1.84 , characterizing median sensitivity. However, the elasticity is lowest in the Amazon and central-western, whilst Northeast Brazil exhibits the highest values (weighted average of 5.53 and variation from 1.51 to 9.79). This result is in agreement with the conclusions obtained by [48] in Australia, where the author observed that stream flow is more sensitive to rainfall changes in drier watersheds. Chiew (2006) [48] found values varying between 2.0 and 
Table 2. Mean elasticity for all periods, scenarios and models.

\begin{tabular}{cc}
\hline Hydrographic region & Elasticity \\
\hline Solimões & 0.84 \\
Negro & 0.54 \\
Madeira & 0.83 \\
Xingu & 0.91 \\
Tapajós & 1.04 \\
Northern Amazon & 0.73 \\
Tocantins & 1.50 \\
Maranhão & 1.51 \\
Parnaíba & 9.79 \\
Northeast Atlantic & 4.15 \\
São Francisco & 4.52 \\
East Atlantic & 8.25 \\
Southeast Atlantic & 1.10 \\
South Atlantic & 1.48 \\
Uruguay & 2.31 \\
Parana & 1.39 \\
Paraguay & 1.58 \\
\hline
\end{tabular}

3.5 in $70 \%$ of the 219 watersheds. IPCC (2014) [49] also notes that watershed sensitivity is highly influenced by the runoff coefficient (runoff-rainfall ratio). The lower the coefficient, the higher the sensitivity of the watershed to climate stimulus (precipitation, temperature and evaporation).

\subsection{Changes of Evapotranspiration and Soil Moisture}

The relation between soil moisture and evapotranspiration is indirectly due to the soil suction, which increases with decreased soil moisture content. Plant roots uptake less water when soil suction is greater.

The soil moisture in Figures 2-4 is calculated with the MGB-IPH and represents the proportion of water in relation to the soil capacity. Observing evapotranspiration maps (Figures 2-4), it is possible to verify that the anomaly of this variable behaves differently in the Amazon and in the Northeast. In the Amazon, the anomaly is positive and in the Northeast, it is negative. Since the precipitation reduces in both regions, evapotranspiration is expected to have negative anomaly in both regions. The positive anomaly of evapotranspiration in the Amazon may be related to the greater capacity of the soil to regulate the evapotranspiration. Despite the lower precipitation in the scenarios, the high soil capacity in the Amazon promotes increased evapotranspiration. In the Northeast, soil storage capacity is lower and, consequently, the moisture condition of the soil affects the plant transpiration. Figures 2-4 also show that soil moisture has a direct relation to precipitation in all regions. 

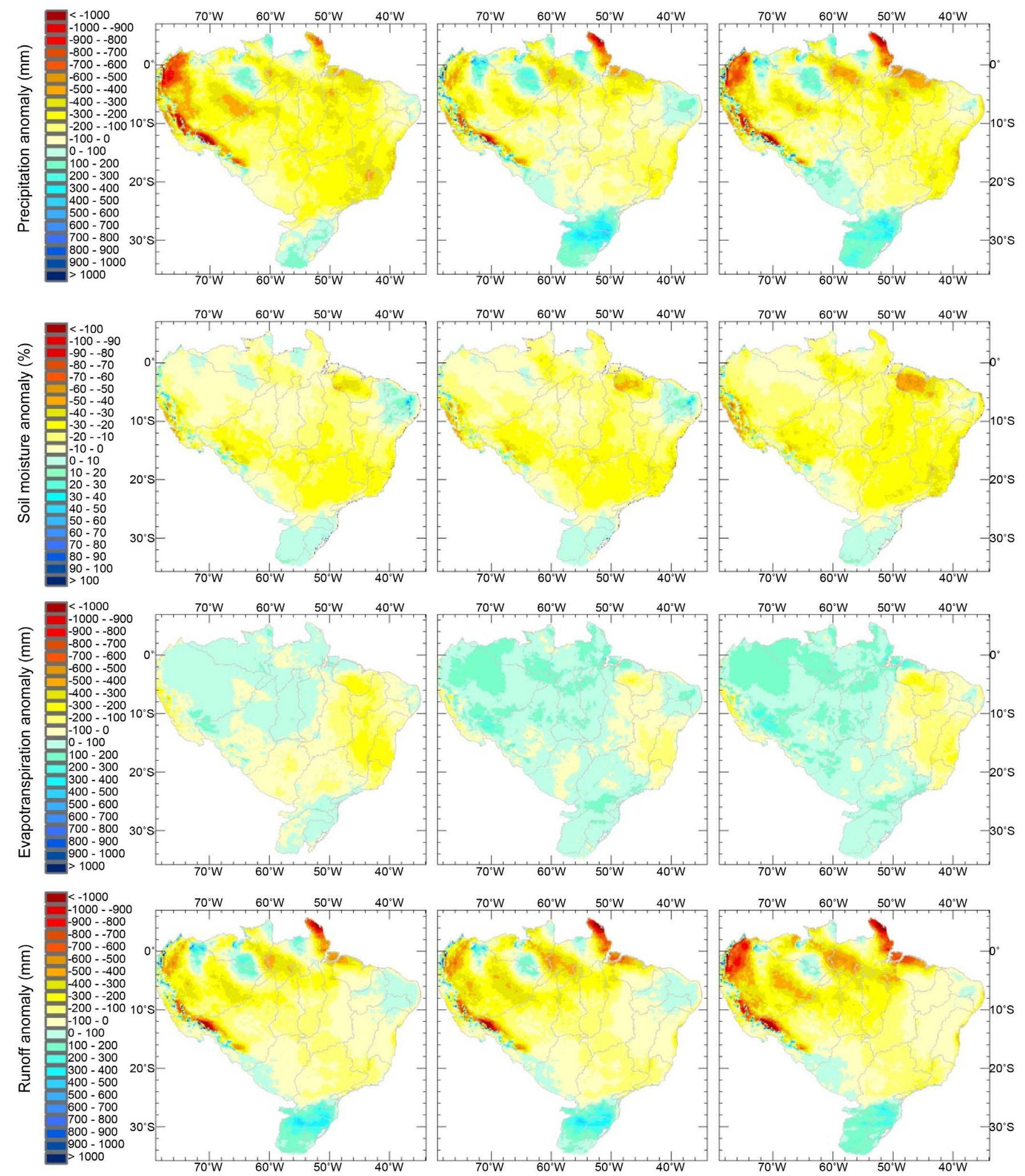

Figure 2. Changes in water budget components with respect to baseline simulations of the MGB-IPH/Eta-HadGEM2-ES under RCP 4.5 scenario. 

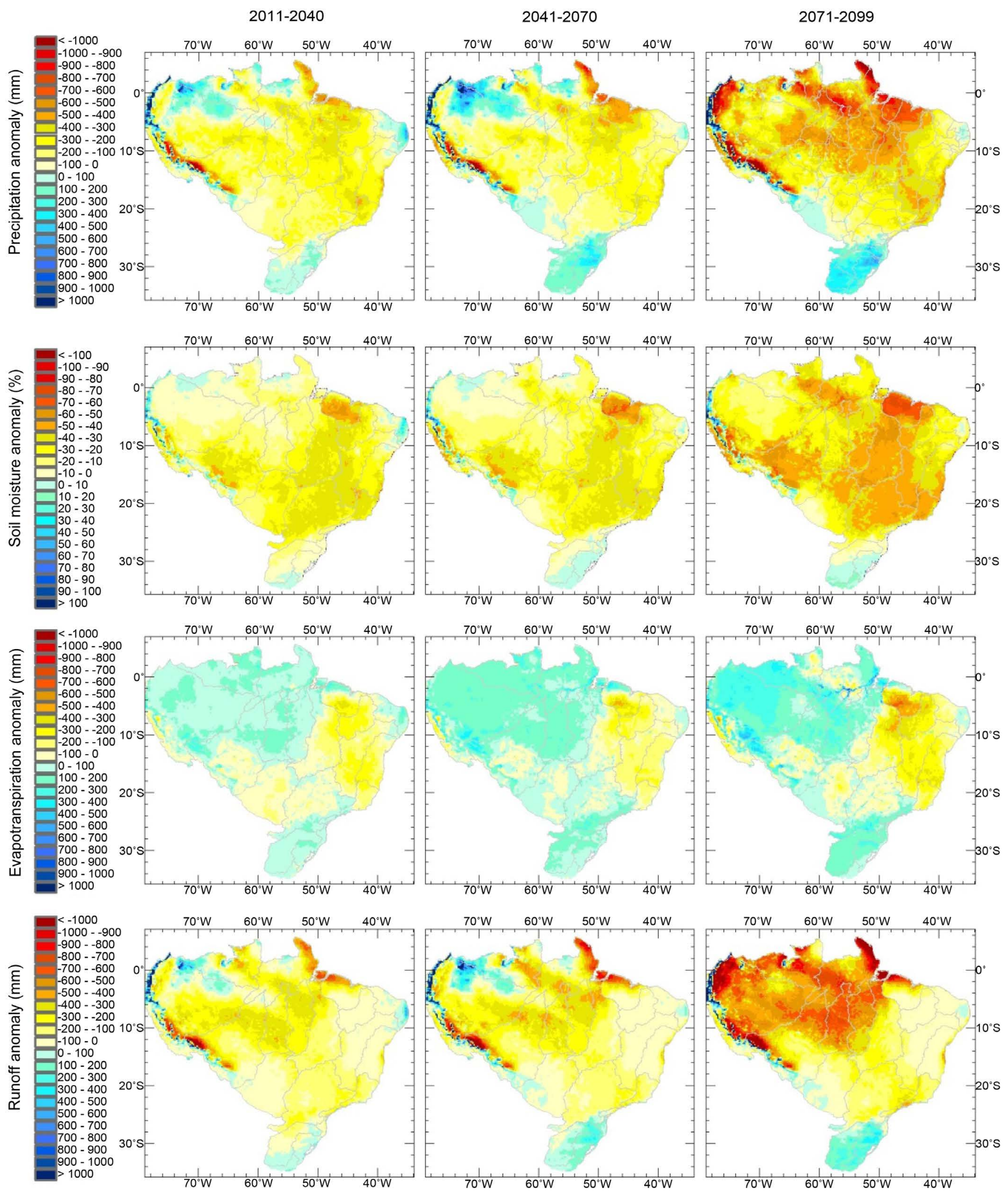

Figure 3. Changes in water budget components with respect to baseline simulations of the MGB-IPH/Eta-HadGEM2-ES under RCP 8.5 scenario. 

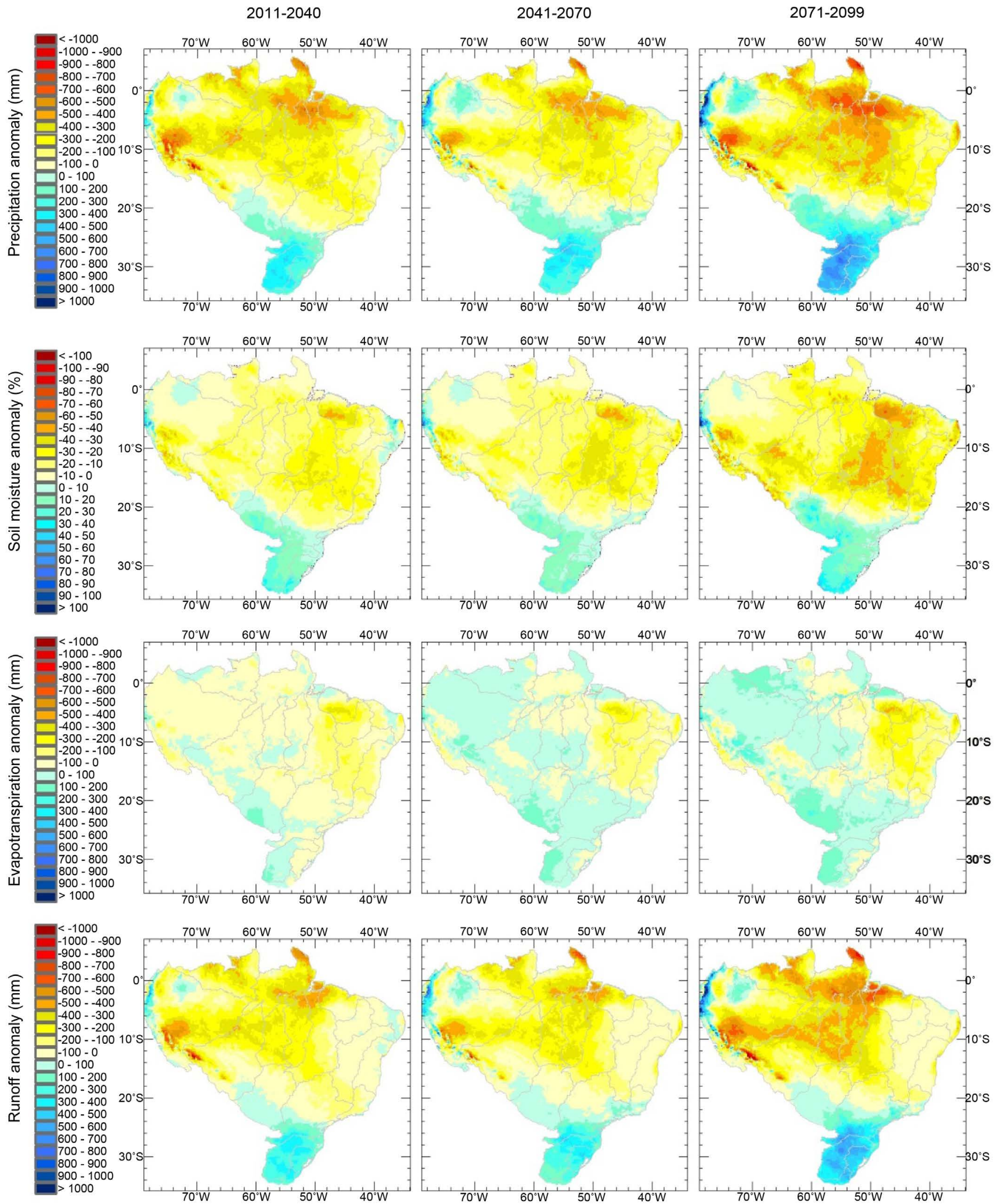

Figure 4. Changes in water budget components with respect to baseline simulations of the MGB-IPH/Eta-MIROC5 under RCP 8.5 scenario. 


\subsection{Water Budget Effects}

The climate change scenarios projected changes in the annual water budget, with a spatial variability as depicted in Figures 2-4. In general, there is a gradient in the patterns of changes projected for each scenario relative to the three time slices, i.e. the changes vary gradually along time. Mostly, a positive or negative change is intensified along time, but in some cases the change gradually dampens until the signal decreases. Because of this, our results are described focusing on the central time slice (2041-2070), with comments regarding the differences for the other two time slices.

For the Eta-HadGEM2-ES RCP 4.5 scenario and time slice 2041-2070, the Peruvian, Colombian and Bolivian Amazon show a strong decrease in precipitation (predominantly between 200 and $300 \mathrm{~mm}$, but with peaks around $1000 \mathrm{~mm}$ in the highest altitude areas) followed by a decrease in soil moisture (mostly between 5\% and 20\%). Projected ET changes present a mixed signal in this region, varying from a decrease of up to $100 \mathrm{~mm}$ in the westernmost part to an increase of up to $200 \mathrm{~mm}$ in the central and eastern parts. These changes in precipitation, soil moisture and ET result in a decreased runoff (mostly between 200 to $400 \mathrm{~mm}$, but reaching peaks greater than $1000 \mathrm{~mm}$ in the Andes). This pattern of impacts on the water budget is the same for the other two time slices, although weaker in the 2011-2040 time slice and stronger in the final time slice (2071-2099).

The results for the central part of Amazon and the central part of Brazil (west of the $50^{\circ} \mathrm{W}$ ) follow in general the previous patterns described for the Peruvian, Colombian and Bolivian regions of Amazon, but with weaker changes. There is a predominance of precipitation reduction, between 50 and $200 \mathrm{~mm}$ and soil moisture reduction, between $5 \%$ and $30 \%$. The projected evapotranspiration tends to increase (around 50 and 200 $\mathrm{mm}$ ) west of the $50^{\circ} \mathrm{W}$ and negative to the east of this location. However, the general pattern for this entire region is of runoff reduction (mostly between 30 and $250 \mathrm{~mm}$ ), but slightly stronger to the west of the $50^{\circ} \mathrm{W}$. Again, the results for the time slices 2011-2040 and 2071-2099 show weaker and stronger changes, respectively, relative to the 2041-2070 time slice.

Southern Brazil show increase of precipitation (between 50 and $400 \mathrm{~mm}$ ), soil moisture (less than 10\%), evapotranspiration (around $50 \mathrm{~mm}$ ) and runoff (between 50 and $400 \mathrm{~mm}$ ) for the 2041-2070 time-slice. This runoff increase occurs for all the time slices. Runoff increase diminishes, however, between the first and the last time slices. Therefore, according to the Eta-HadGEM2-ES RCP 4.5 simulations, there is initially an increase of runoff but this effect tends to reduce over time.

In the Northeast region of Brazil, results show a dual pattern. There is an area that follows the same pattern described for South Brazil, but the anomalies of the hydrological variables are weaker: increase of precipitation, soil moisture and evapotranspiration that also results in a small runoff increase (less than $50 \mathrm{~mm}$ ). Again, change is dampened along the three time-slices. The larger area around this core part and also a $\sim 100-\mathrm{km}$ narrow strip along the coast follow the patterns of projected changes described for the central part of Brazil (east of the $50^{\circ}$-meridian) for the following: precipitation, soil 
moisture, evapotranspiration and runoff reduction.

Considering the scenario results of the Eta-HadGEM2-ES RCP 8.5, in general it is clear the maintenance of the patterns described for the previous scenario, with an increase of the changes along time (from the first to the last time slice). Large portions of Brazil, including central and northern Amazon, central Brazil and part of southeast, present precipitation reduction between 300 and $800 \mathrm{~mm}$ and soil moisture reduction between $25 \%$ and $70 \%$ for the 2071-2099 time slice. The evapotranspiration increase (reduction) to the west (east) of the $50^{\circ}$-meridian shown in Eta-HadGEM2-ES RCP 4.5 scenario is intensified in the Eta-HadGEM2-ES RCP 8.5 scenario.

The result of the projected water budget for this scenario is a runoff decrease ranging between 20 and $200 \mathrm{~mm}$ for most of the studied area in all of the three time slices. Some areas in the central Amazon present even higher reduction, with the runoff reaching up to $350 \mathrm{~mm}$ in the 2011-2040 time slice, and this pattern intensifies and expands spatially over time, in such a way that for the furthest time slice almost the entire Amazon basin presents a runoff reduction ranging between 300 and $800 \mathrm{~mm}$, with peaks of up to $2000 \mathrm{~mm}$ in highest altitude areas.

In the South Brazil, the Eta-HadGEM2-ES RCP 8.5 scenario leads to precipitation increase greater than in the Eta-HadGEM2-ES RCP 4.5 scenario. However, the runoff increase in the RCP 8.5 scenario is slightly smaller than in the RCP 4.5 scenario, with an additional relevant difference: the runoff increase raises along the three time slices in the 8.5 scenario, while it reduces along time for the first emission scenario.

In general, the Eta-MIROC-ES RCP 8.5 scenario projected changes following the spatial patterns described for both Eta-HadGEM2 scenarios. However, the intensity of MIROC-ES RCP 8.5 may be considered as intermediate impact between HadGEM2-ES RCP 4.5 and RCP 8.5 scenarios.

\subsection{Impacts on Seasonal Runoff and Extreme Discharges}

One possible impact of the change of the climate is the shift and duration of the seasons. This may mean summer or winter starting earlier or later, being shorter or longer, wetter or drier. Figure 5 and Figure 6 show the anomalies of the mean runoff for austral summer (DJF) and winter (JJA), respectively. The seasonal anomalies follow a similar pattern to the runoff impacts with decreases in the Amazon, the Northeast and Central Brazil and an increase in the South. However, the anomalies are more remarkable in the summer. During the winter, the South Amazon is less impacted than during the summer. In the South region of Brazil, the anomaly in the winter is still positive, the intensity of the anomaly signal is lower and the impacted area is smaller, when compared with summer.

Table 3 exhibits the projected seasonal amplitude for the period 2041-2070 as a percentage of the baseline simulations. Negative values indicate reduction of the seasonal amplitude and positive values mean increase of the amplitude. The values indicate a relationship between mean annual runoff changes and the value of the seasonal amplitude change. 


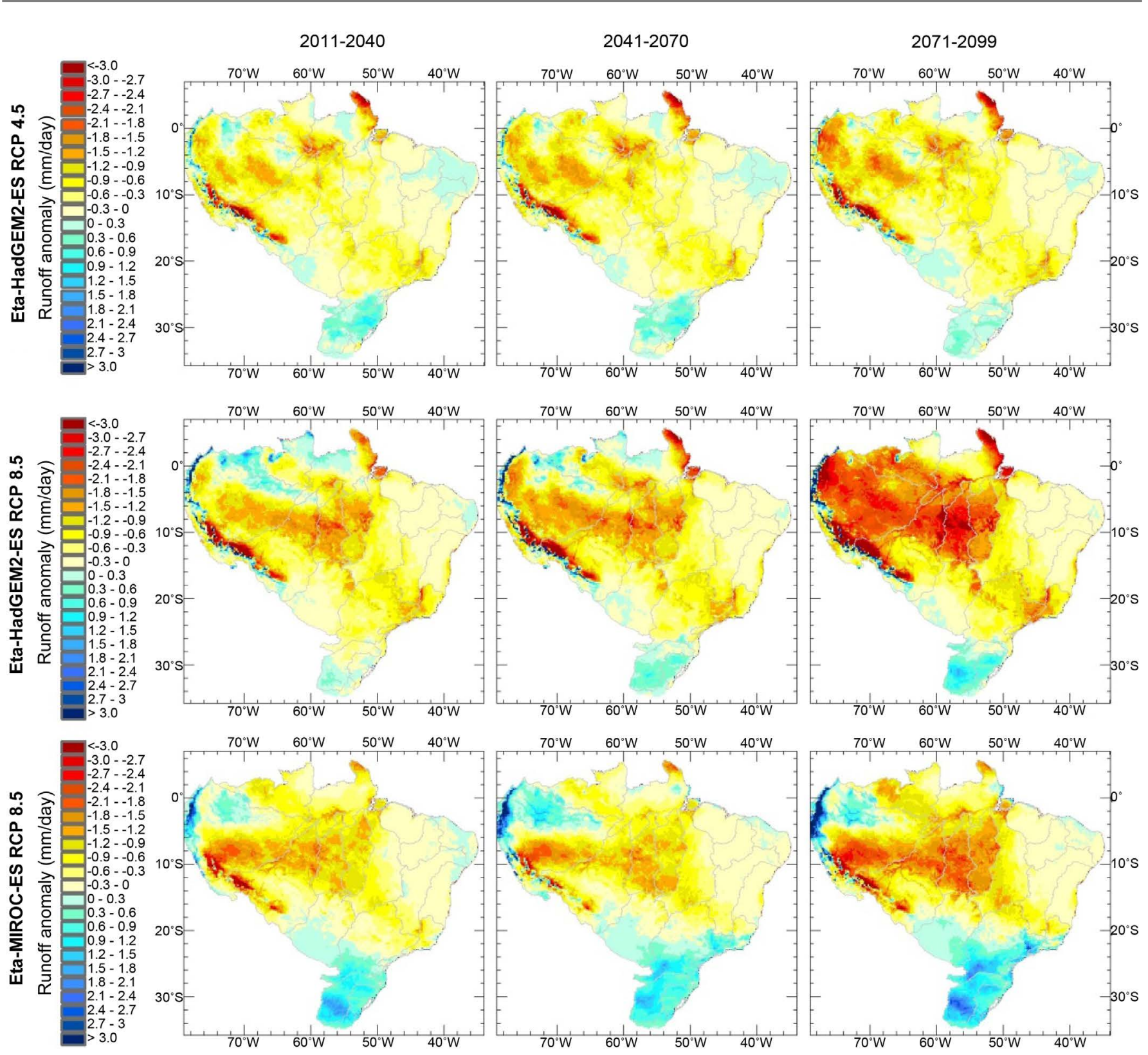

Figure 5. Changes of DJF (austral summer) mean runoff ( $\mathrm{mm} /$ day) with respect to the baseline.

The extreme discharges may also change in the future climate scenarios. Figure 7 and Figure 8 verify that the pattern of impacts is similar to the seasonality impacts. South Brazil exhibits positive anomaly for high-flow and low-flow discharges in similar areas for the Eta-MIROC5 model. The Eta-HadGEM-ES model results also have positive anomaly in the South, but with restricted areas for low-flow discharge. The worst situation happens when the anomaly is positive for high-flow discharge and negative for low-flow discharge. In other words, there would be an intensification of extreme discharges, leading to a condition of more natural disasters related to floods and droughts in the same area. This characteristic may be observed in the Northwest Amazon and in a small area in the Northeast Atlantic. 


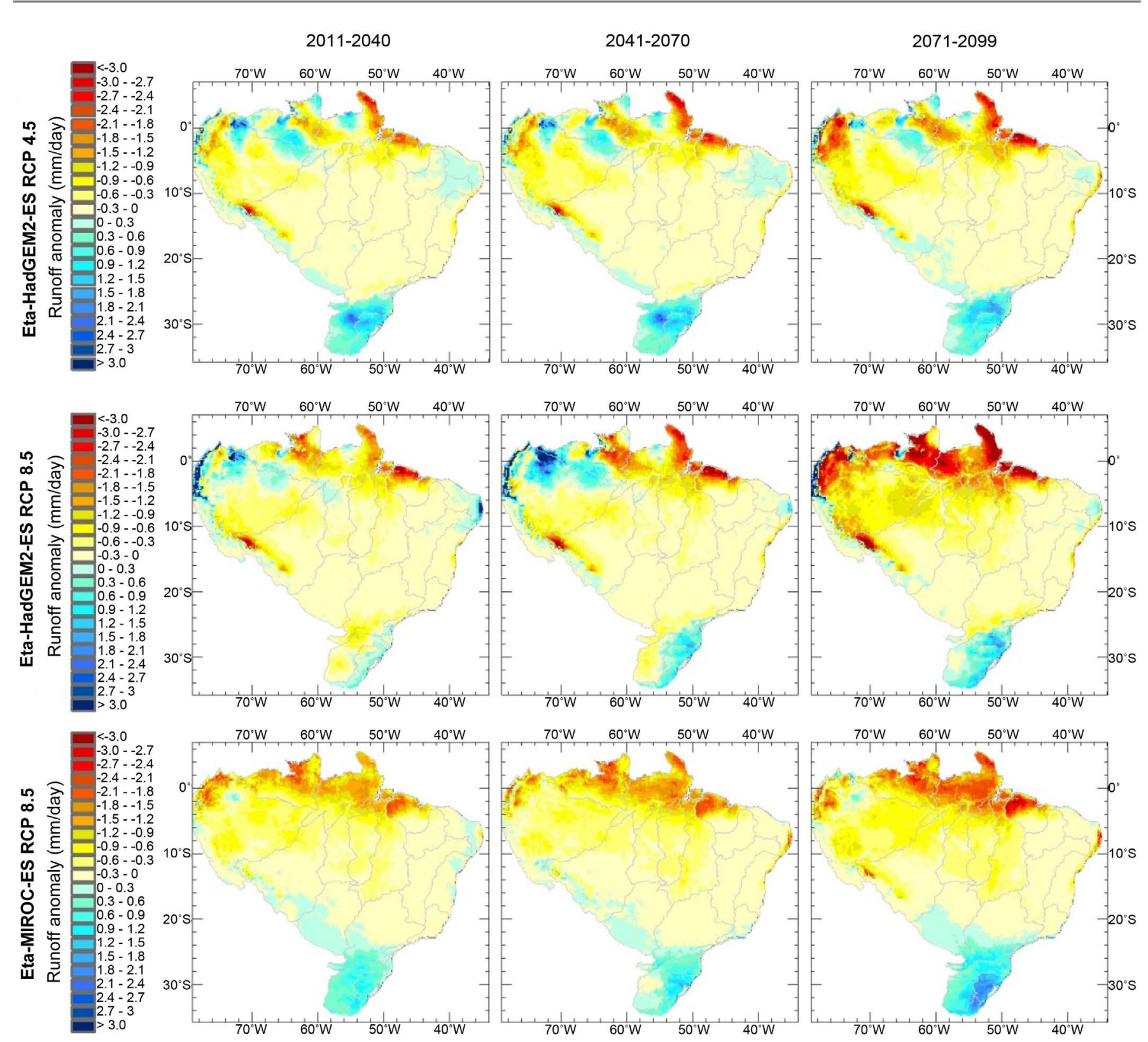

Figure 6. Changes of JJA (austral winter) mean runoff ( $\mathrm{mm} /$ day) with respect to the baseline.

\subsection{Discussion}

The spatial pattern of the runoff anomalies is quite similar to the results of studies that use global hydrological modelling [6] [50] [51], but disagree with the results of studies such as [7], which found positive anomalies in the Amazon and parts of Northeast and [52], who verified runoff decrease in South Brazil using climate and hydrological multimodel.

Analysis of hydropower-producing river basins shows the expressive impact arising from the stream flow regime change. The Parana River basin projections indicate discharge increase for Eta-MIROC5 and reduction for Eta-HadGEM2-ES. São Francisco and Tocantins River basins exhibit discharge reduction for both climate models and all 
Table 3. Seasonal amplitude for the period 2041-2070 as percentage of the baseline simulations: (1) MGB-IPH/Eta-HadGEM2-ES RCP 4.5, (2) MGB-IPH/Eta-HadGEM2-ES RCP 8.5, (3) MGBIPH/Eta-MIROC5 RCP 8.5.

\begin{tabular}{lccc}
\hline Hydrographic region & $(1)$ & $(2)$ & $(3)$ \\
\hline Solimões & -16.4 & 13.1 & 26.5 \\
Negro & 10.9 & 4.6 & -10.2 \\
Madeira & -22.4 & -31.1 & -15.9 \\
Xingu & -18.9 & -34.4 & -17.9 \\
Tapajós & -17.3 & -37.6 & -21.7 \\
Northern Amazon & -22.6 & -15.0 & -24.1 \\
Tocantins & -28.5 & -48.2 & -39.4 \\
Maranhão & -66.0 & -86.6 & -59.4 \\
Parnaíba & -12.1 & -65.6 & -59.1 \\
Northeast Atlantic & -6.4 & 1.7 & -48.6 \\
São Francisco & -29.3 & -62.7 & -41.2 \\
East Atlantic & -10.3 & -52.3 & -2.2 \\
Southeast Atlantic & 29.7 & 29.4 & 35.7 \\
South Atlantic & 89.4 & 90.7 & 89.9 \\
Uruguay & 70.2 & 27.1 & 33.6 \\
Parana & -28.9 & -44.8 & -6.2 \\
Paraguay & -25.9 & -37.8 & \\
\hline
\end{tabular}

scenarios. The most severe reduction is projected for the Tocantins River basin, reaching values between $50 \%$ and $60 \%$. Those three river basins have about $73.0 \%$ of the installed power of all hydroelectric power plants of Brazil.

The indirect relation between the anomalies of precipitation and evapotranspiration has also been verified in Central Europe by [53]. The study of [54] in the Xingu River Basin used a numerical model to evaluate the influence of the climate on the water budget. The results suggest a decrease of about $2 \%$ in precipitation and $+3 \%$ increase in evapotranspiration. Similar behavior was found with MGB-IPH in the future-climate scenarios simulations for the Amazon region: negative anomaly for precipitation and positive anomaly for evapotranspiration.

The seasonal amplitude of the discharge may be related to the relative variability in stream flow along the year. The results showed positive seasonal amplitude in hydrographic regions of South Brazil, meaning an increase of relative variability in stream flow. This is coincident with the increase of the average annual stream flow in the same region. Arnell and Gosling (2013) [6] have concluded the relative variability and annual stream flow change in parallel, which is in agreement with the results obtained in this study. 


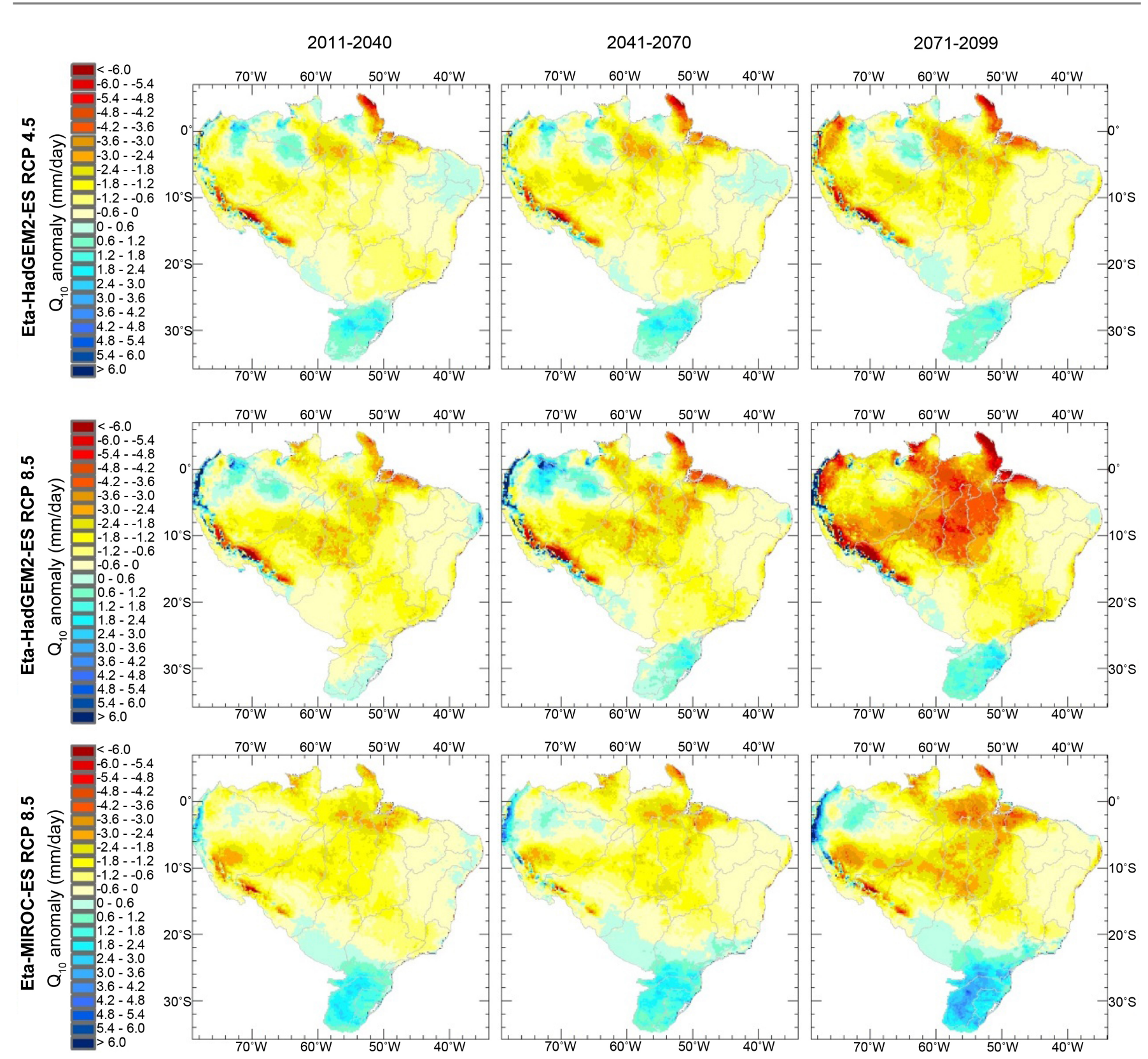

Figure 7. Changes of maximum discharge $\left(Q_{10}\right)(\mathrm{mm} /$ day) with respect to the baseline.

\section{Conclusions}

Projections of changes in the hydrological regimes of the major Brazilian basins are assessed in this work. The projections agree partially with the conclusions on the runoff anomalies pointed out by earlier studies. For example, river discharge should increase in mid-high latitudes and that the sensitivity of the catchment influences the magnitude of the impact [49]. The hydrographic regions in South Brazil are located in mid-latitudes and exhibit positive anomaly. On the other hand, considering that the smaller the ratio runoff to precipitation, the greater the catchment sensitivity, Northeast Brazil should exhibit the most severe results as compared to the Amazon region. 


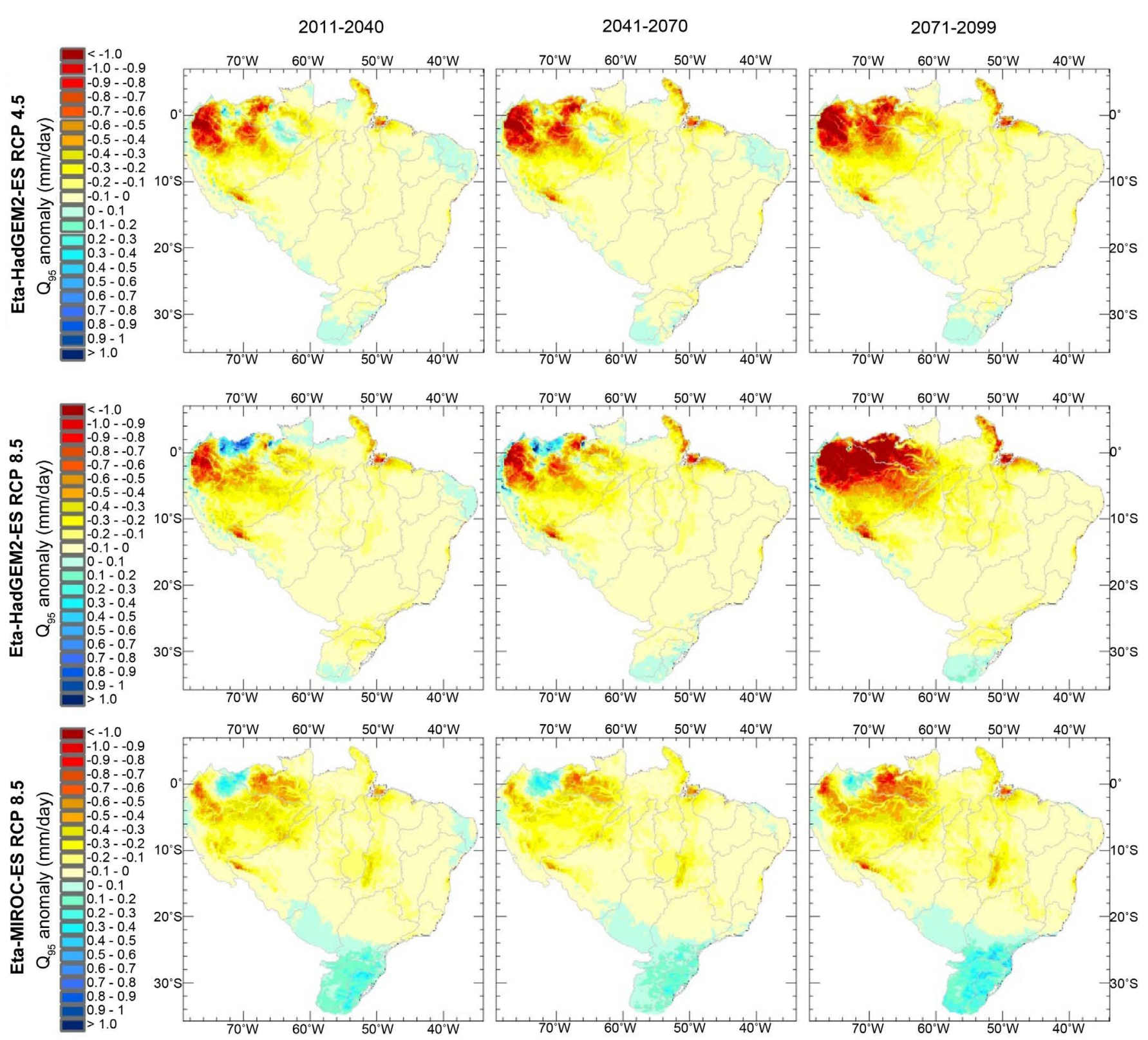

Figure 8. Changes of minimum discharge $\left(Q_{95}\right)(\mathrm{mm} /$ day) with respect to the baseline.

The assessment of the average annual runoff anomaly in the hydrographic regions shows projected reduction of water availability in almost the entire country. The exception is the South region of Brazil. The Northwest, Amazon and a small area along the Northeast Atlantic coast exhibited intensification of the extremes discharges, where the anomaly is positive for high-flow $\left(Q_{10}\right)$ and negative for low-flow $\left(Q_{95}\right)$. The increase of high-flow is worrying for regions such as Southeast Atlantic, South Atlantic, Uruguay and Paraná due to high population density, while the highest decreases of the low-flow were verified in the Northwest Amazon. Considering the extreme flood and drought events that affected those regions during the past 10 years, the projected changes may trigger the occurrence of natural disasters such as droughts and flash floods, which 
could increase vulnerability of people living in risk areas.

Considering the climate change impacts in the agriculture, possible adaptation measures are the expansion of irrigated land and enhancement of the irrigation methods [55]. In Brazil, regions with agricultural vocation such as Paraná basin and others with high dependency on irrigation such as São Francisco river basin must receive special attention to pursuit adaptation to climate change with respect to agriculture production.

Despite the uncertainties associated with climate and hydrological modelling, it is very likely that the hydrological characteristics in the river basin scale will change in the future [56]. Given this, some countries and regions in the world are developing procedures for adaptation and risk management practices that try to incorporate the likely changes in the hydrological regimes [56]. The results of our study point out a similar hydrological condition in Brazil compared to other countries and regions in the world in terms of hydrological regime change up to the end of the 21st century. Adaptation procedures are related to measures of water availability on one hand, and water consumption on the other. Water availability measures refer to the extension of the water infrastructure. However, these measures have physical, environmental and economic constraints. Demand-side measures refer to actions that emphasize the reduction of water loss in the water supply systems, enhancement of the irrigation systems and extension of the water reuse [49].

\section{Acknowledgements}

This paper is a contribution of the Brazilian Network on Global Climate Change Research funded by CNPq Grant Number 550022/2014-7 and FINEP Grant Number 01.13.0353.00. This work was also partially funded by CNPq Grant Number 400792/2012-5. The authors acknowledge the Ministry of Science, Technology and Innovation of Brazil for supporting the work through Global Environmental Facility funding (UNDP BRA/10/G32) within the Third National Communication to the United Nations Framework Convention on Climate Change. The English text of this paper was revised by Sidney Pratt, Canadian, MAT (The Johns Hopkins University), RSAdip-TESL (Cambridge University).

\section{References}

[1] Magrin, G.O., et al. (2014) Central and South America. In: Barros, V.R., et al., Eds., Climate Change 2014: Impacts, Adaptation, and Vulnerability, Part B: Regional Aspects, Cambridge University Press, Cambridge, 1499-1566.

[2] Ribeiro Neto, A., Scott, C.A., Lima, E.A., Montenegro, S.M.G.L. and Cirilo, J.A. (2014) Infrastructure Sufficiency in Meeting Water Demand under Climate-Induced Socio-Hydrological Transition in the Urbanizing Capibaribe River Basin-Brazil. Hydrology and Earth System Sciences, 18, 3449-3459. http://dx.doi.org/10.5194/hess-18-3449-2014

[3] Siqueira Jr., J.L., Tomasella, J. and Rodriguez, D.A. (2015) Impacts of Future Climatic and Land Cover Changes on the Hydrological Regime of the Madeira River Basin. Climatic Change, 129, 117-129. http://dx.doi.org/10.1007/s10584-015-1338-x 
[4] Nóbrega, M.T., Collischonn, W., Tucci, C.E.M. and Paz, A.R. (2011) Uncertainty in Climate Change Impacts on Water Resources in the Rio Grande Basin, Brazil. Hydrology and Earth System Sciences, 15, 585-595. http://dx.doi.org/10.5194/hess-15-585-2011

[5] Gosling, S.N. and Arnell, N.W. (2011) Simulating Current Global River Runoff with a Global Hydrological Model: Model Revisions, Validation, and Sensitivity Analysis. Hydrological Processes, 25, 1129-1145. http://dx.doi.org/10.1002/hyp.7727

[6] Arnell, N.W. and Gosling, S.N. (2013) The Impacts of Climate Change on River Flow Regimes at the Global Scale. Journal of Hydrology, 486, 351-364. “ http://dx.doi.org/10.1016/j.jhydrol.2013.02.010

[7] Nakaegawa, T., Kitoh, A. and Hosaka, M. (2013) Discharge of Major Global Rivers in the Late 21st Century Climate Projected with the High Horizontal Resolution MRI-AGCMs. Hydrological Processes, 27, 3301-3318. http://dx.doi.org/10.1002/hyp.9831

[8] Milly, P.C.D., Dunne, K.A. and Vecchia, A.V. (2005) Global Pattern of Trends in Streamflow and Water Availability in a Changing Climate. Nature, 438, 347-350.

http://dx.doi.org/10.1038/nature04312

[9] Jung, I.W., Bae, D.H. and Lee, B.J. (2013) Possible Change in Korean Streamflow Seasonality Based on Multi-Model Climate Projections. Hydrological Processes, 27, 1033-1045. http://dx.doi.org/10.1002/hyp.9215

[10] Zuo, D., Xu, Z., Zhao, J., Abbaspour, K.C. and Yang, H. (2015) Response of Runoff to Climate Change in the Wei River Basin, China. Hydrological Sciences Journal, 60, 508-522. http://dx.doi.org/10.1080/02626667.2014.943668

[11] Demirel, M.C., Booij, M.J. and Hoekstra, A.Y. (2013) Impacts of Climate Change on the Seasonality of Low Flows in 134 Catchments in the River Rhine Basin Using an Ensemble of Bias-Corrected Regional Climate Simulations. Hydrology and Earth System Sciences, 17, 4241-4257. http://dx.doi.org/10.5194/hess-17-4241-2013

[12] Ribeiro Neto, A., Silva, R.C.V., Collischonn, W. and Tucci, C.E. (2011) Hydrological Simulation in Amazonia: The Madeira River. In: Silva, R.C.V., Tucci, C.E.M. and Scott, C.A., Eds., Water and Climate Modeling in Large Basins, Brazilian Water Resources Association, Porto Alegre, 127-152.

[13] Montenegro, S.M.G.L. and Ragab, R. (2012) Impact of Possible Climate and Land Use Changes in the Semiarid Regions: A Case Study from North Eastern Brazil. Journal of Hydrology, 434, 55-68. http://dx.doi.org/10.1016/j.jhydrol.2012.02.036

[14] Marengo, J.A., et al. (2012) Development of Regional Future Climate Change Scenarios in South America Using the Eta CPTEC/HadCM3 Climate Change Projections: Climatology and Regional Analyses for the Amazon, São Francisco and the Parana River Basins. Climate Dynamics, 38, 1829-1848. http://dx.doi.org/10.1007/s00382-011-1155-5

[15] Palmer, M.A., Reidy, L.C.A., Nilsson, C., Flörke, M., Alcamo, J., Lake, P.S. and Bond, N. (2008) Climate Change and the World's River Basins: Anticipating Management Options. Frontiers in Ecology and the Environment, 6, 81-89. http://dx.doi.org/10.1890/060148

[16] Valverde, M.C. and Marengo, J.A. (2014) Extreme Rainfall Indices in the Hydrographic Basins of Brazil. Open Journal of Modern Hydrology, 4, 10-26.

http://dx.doi.org/10.4236/ojmh.2014.41002

[17] Kundzewicz, Z.W., et al. (2007) Fresh Water Resources and Their Management. In: Parry, M.L., Canziani, O., Palutikof, J., van der Linden, P. and Hanson, C., Eds., Climate Change 2007: Impacts, Adaptation and Vulnerability, Cambridge University Press, Cambridge, 173210.

[18] Viola, M.R., De Mello, C.R., Chou, S.C., Yanagi, S.N. and Gomes, J.L. (2014) Assessing 
Climate Change Impacts on Upper Grande River Basin Hydrology, Southeast Brazil. International Journal of Climatology, 35, 1054-1068. http://dx.doi.org/10.1002/joc.4038

[19] Saurral, R.I., Barros, V.R. and Lettenmaier, D.P. (2008) Land Use Impact on the Uruguay River Discharge. Geophysical Research Letters, 35, Article ID: L12401. http://dx.doi.org/10.1029/2008gl033707

[20] Doyle, M.E. and Barros, V.R. (2011) Attribution of the River Flow Growth in the Plata Basin. International Journal of Climatology, 31, 2234-2248. http://dx.doi.org/10.1002/joc.2228

[21] Marengo, J.A. and Espinoza, J.C. (2015) Extreme Seasonal Droughts and Floods in Amazonia: Causes, Trends and Impacts. International Journal of Climatology, 36, 1033-1050. http://dx.doi.org/10.1002/joc. 4420

[22] Lavado, C.W.S., Ronchail, J., Labat, D., Espinoza, J.C. and Guyot, J.L. (2012) Basin-Scale Analysis of Rainfall and Runoff in Peru (1969-2004): Pacific, Titicaca and Amazonas Drainages. Hydrological Sciences Journal, 57, 625-642. http://dx.doi.org/10.1080/02626667.2012.672985

[23] Carmona, A. and Poveda, G. (2011) Identificación de Modos Principales de Variabilidad Hidroclimática en Colombia Mediante la Transformada de Hilbert-Huang. Proceedings of the 9 th Congreso Colombiano de Meteorología, National University of Colombia, Bogotá, 23-25 May 2011. (In Spanish)

[24] Dai, A., Qian, T., Trenberth, K.E. and Milliman, J.D. (2009) Changes in Continental Freshwater Discharge from 1948 to 2004. Journal of Climate, 22, 2773-2792. http://dx.doi.org/10.1175/2008JCLI2592.1

[25] Mesinger, F., Janjic, Z.I., Nickovic, S., Gavrilov, D. and Deaven, D.G. (1988) The Step-Mountain Coordinate: Model Description, and Performance for Cases of Alpine Lee Cyclogenesis and for a Case of an Appalachian Redevelopment. Monthly Weather Review, 116, 1493-1518. http://dx.doi.org/10.1175/1520-0493(1988)116<1493:TSMCMD>2.0.CO;2

[26] Black, T.L. (1994) The New NMC Mesoscale Eta Model: Description and Forecast Examples. Weather Analysis and Forecasting, 9, 265-278. http://dx.doi.org/10.1175/1520-0434(1994)009<0265:TNNMEM>2.0.CO;2

[27] Janjić, Z.I. (1994) The Step-Mountain Eta Coordinate Model: Further Developments of the Convection, Viscous Sublayer and Turbulence Closure Schemes. Monthly Weather Review, 122, 927-945. http://dx.doi.org/10.1175/1520-0493(1994)122<0927:TSMECM>2.0.CO;2

[28] Chou, S.C. (1996) Modelo Regional Eta. Climanálise 1, Special Edition, Instituto Nacional de Pesquisas Espaciais, São José dos Campos.

[29] Chou, S.C., Bustamante, J.F. and Gomes, J.L. (2005) Evaluation of Eta Model Seasonal Precipitation Forecasts over South America. Nonlinear Processes in Geophysics, 12, 537-555. http://dx.doi.org/10.5194/npg-12-537-2005

[30] Pesquero, J.F., Chou, S.C., Nobre, C.A. and Marengo, J.A. (2009) Climate Downscaling over South America for 1961-1970 Using the Eta Model. Theoretical and Applied Climatology, 99, 75-93. http://dx.doi.org/10.1007/s00704-009-0123-z

[31] Chou, S.C., et al. (2012) Downscaling of South America Present Climate Driven by 4-Member HadCM3 Runs. Climate Dynamics, 38, 635-653. http://dx.doi.org/10.1007/s00382-011-1002-8

[32] Mesinger, F. (1984) A Blocking Technique for Representation of Mountains in Atmospheric Models. Rivista di Meteorologia Aeronautica, 44, 195-202.

[33] Figueroa, S.N., Satyamurty, P. and Dias, P.L.S. (1995) Simulations of the Summer Circulation over the South American Region with an Eta Coordinate Model. Journal of the Atmospheric Sciences, 52, 1573-1584. 
http://dx.doi.org/10.1175/1520-0469(1995)052<1573:SOTSCO >2.0.CO;2

[34] Mesinger, F. (2012) An Upgraded Version of the Eta Model. Meteorology and Atmospheric Physics, 116, 63-79. http://dx.doi.org/10.1007/s00703-012-0182-Z

[35] Chou, S.C., et al. (2014) Evaluation of the Eta Simulations Nested in Three Global Climate Models. American Journal of Climate Change, 3, 438-454. http://dx.doi.org/10.4236/ajcc.2014.35039

[36] Chou, S.C., et al. (2014) Assessment of Climate Change over South America under RCP 4.5 and 8.5 Downscaling Scenarios. American Journal of Climate Change, 3, 512-525. http://dx.doi.org/10.4236/ajcc.2014.35043

[37] New, M., Lister, D., Hulme, M. and Makin, I. (2002) A High-Resolution Data Set of Surface Climate over Global Land Areas. Climate Research, 21, 1-25. http://dx.doi.org/10.3354/cr021001

[38] Bárdossy, A. and Pegram, G. (2011) Downscaling Precipitation Using Regional Climate Models and Circulation Patterns toward Hydrology. Water Resources Research, 47, 1-18. http://dx.doi.org/10.1029/2010WR009689

[39] Collischonn, W., Allasia, D., Silva, B.C. and Tucci, C.E.M. (2007) The MGB-IPH Model for Large-Scale Rainfall-Runoff Modelling. Hydrological Sciences Journal, 52, 878-895. http://dx.doi.org/10.1623/hysj.52.5.878

[40] Silva, B.C., Collischonn, W. and Tucci, C.E.M. (2006) Stream-Flow Forecasting with Hydroclimatic Models. Brazilian Water Resources Journal, 11, 15-29. (In Portuguese)

[41] Bayer, D.M. and Collischonn, W. (2013) Land-Use Sensitivity Analysis in MGB-IPH Model. Brazilian Water Resources Journal, 18, 165-179. (In Portuguese)

[42] Zhao, R.J. (1992) The Xinanjiang Model Applied in China. Journal of Hydrology, 135, 371 381. http://dx.doi.org/10.1016/0022-1694(92)90096-E

[43] Paiva, R.C.D., Collischonn, W. and Buarque, D.C. (2013) Validation of a Full Hydrodynamic Model for Large-Scale Hydrologic Modelling in the Amazon. Hydrological Processes, 27, 333-346. http://dx.doi.org/10.1002/hyp.8425

[44] FAO (Food and Agriculture Organization) (2003) The Digital Soil Map of the World. Food and Agriculture Organization, the United Nations, Version 3.6.

[45] Eva, H.D., De Miranda, E.E., Di Bella, C.M. and Gond, V. (2002) A Vegetation Map of South America. EUR 20159 EN, European Commission, Luxembourg.

[46] Lehner, B., Verdin, K. and Jarvis, A. (2006) HydroSHEDS. Technical Documentation. Version 1.0. http://hydrosheds.cr.usgs.gov/webappcontent/HydroSHEDS_TechDoc_v10.pdf

[47] Paz, A.R., Tucci, C.E.M. and Collischonn, W. (2013) The Pantanal: Hydrologic Behavior and Its Simulation. In: Silva, R.C.V., Tucci, C.E.M. and Scott, C.A., Eds., Water and Climate Modeling in Large Basins, Vol. 2, Brazilian Water Resources Association, Porto Alegre, 53-90.

[48] Chiew, F.H.S. (2006) Estimation of Rainfall Elasticity of Streamflow in Australia. Hydrological Sciences Journal, 51, 613-625. http://dx.doi.org/10.1623/hysj.51.4.613

[49] IPCC (2014) Climate Change 2014: Impacts, Adaptation, and Vulnerability. Part A: Global and Sectoral Aspects. Contribution of Working Group II to the 5th Assessment Report of the Intergovernmental Panel on Climate Change, Field, C.B., et al., Eds., Cambridge University Press, Cambridge.

[50] Arnell, N.W. and Lloyd-Hughes, B. (2014) The Global-Scale Impacts of Climate Change on Water Resources and Flooding under New Climate and Socio-Economic Scenarios. Climatic Change, 122, 127-140. http://dx.doi.org/10.1007/s10584-013-0948-4 
[51] Fung, F., Lopez, A. and New, M. (2011) Water Availability in $+2^{\circ} \mathrm{C}$ and $+4^{\circ} \mathrm{C}$ Worlds. Philosophical Transactions of the Royal Society A, 369, 99-116. http://dx.doi.org/10.1098/rsta.2010.0293

[52] Schewe, J., et al. (2013) Multi-Model Assessment of Water Scarcity under Climate Change. Proceedings of the National Academy of Sciences of the United States of America, 111, 3245-3250. http://dx.doi.org/10.1073/pnas.1222460110

[53] Seneviratne, S.I., Corti, T., Davin, E.L., Hirschi, M., Jaeger, E.B., Lehner, I., Orlowsky, B. and Teuling, A.J. (2010) Investigating Soil Moisture-Climate Interactions in a Changing Climate: A Review. Earth-Science Reviews, 99, 125-161.

http://dx.doi.org/10.1016/j.earscirev.2010.02.004

[54] Panday, P.K., Coe, M.T., Macedo, M.N., Lefebvre, P. and Castanho, A.D.A. (2015) Deforestation Offsets Water Balance Changes Due to Climate Variability in the Xingu River in Eastern Amazonia. Journal of Hydrology, 523, 822-829.

http://dx.doi.org/10.1016/j.jhydrol.2015.02.018

[55] McDonald, R.I. and Girvetz, E.H. (2013) Two Challenges for US Irrigation Due to Climate Change: Increasing Irrigated Area in Wet States and Increasing Irrigation Rates in Dry States. PLOS ONE, 8, e65589. http://dx.doi.org/10.1371/journal.pone.0065589

[56] Bates, B.C., Kundzewicz, Z.W., Wu, S. and Palutikof, J.P. (2008) Climate Change and Water. Technical Paper of the Intergovernmental Panel on Climate Change, IPCC Secretariat, Geneva.

\section{Submit or recommend next manuscript to SCIRP and we will provide best service} for you:

Accepting pre-submission inquiries through Email, Facebook, LinkedIn, Twitter, etc.

A wide selection of journals (inclusive of 9 subjects, more than 200 journals)

Providing 24-hour high-quality service

User-friendly online submission system

Fair and swift peer-review system

Efficient typesetting and proofreading procedure

Display of the result of downloads and visits, as well as the number of cited articles

Maximum dissemination of your research work

Submit your manuscript at: http://papersubmission.scirp.org/

Or contact jwarp@scirp.org 